TURIZAM

Volume 24, Issue 2

79-90 (2020)

ORIGINAL

SCIENTIFIC PAPER

\title{
The Impact of Social Media in Travel Decision-making Process among the $Y$ and $Z$ Generations of Music Festivals in Serbia and Hungary
}

\author{
Dorottya Süli^*${ }^{*}$, Zita Martyin-CsamangóA \\ Received: January 2020 | Accepted: April 2020 \\ DOI: $10.5937 /$ turizam\%v-24678
}

\begin{abstract}
As a remarkable trend, social media is becoming a primary source of information and impressions about tourism destinations. Travelers, especially the young generations are using intensively the information from the web in their decisions and they have widely adopted social media in order to search for advice, share and annotate their experiences. The recent shift towards more visual content can even more strongly affect others' consumption habits, (touristic) decisions, image and opinions on different places and events. Knowing about traveling habits and decision-making processes of young generations can be useful for the tourism service suppliers, because their habits can substantially affect the future tourism development directions. The aim of this study was to analyze the role and importance of social media usage in travel decision-making among the young participants of music festivals in Vojvodina and Hungary. On the one hand, we made a questionnaire survey among the participants of two festivals from the $Y$ and $Z$ generations in the study area (in Green Future of Ada and in the Youth Days of Szeged), and among the students from the University of Szeged, who usually visit festivals. As social media can indirectly contribute to the promotion of festivals and settlements through the public posts of the festivals, on the other hand we analyzed the posts of the selected music festivals on a photo-sharing site (Instagram), searching the hashtags which refer to the places of the festivals. Based on the results it can be concluded that young people's travel and festival decisions are considerably influenced by social media, so the role of online marketing can be significant to reach these generations. Therefore, the shared social media content linked to festivals can make some places better known by shaping their image. With the improved image these posts can contribute to attracting more tourists.
\end{abstract}

Keywords: Social Media, Y and Z Generations, Tourists' Decisions, Festival Tourism, Destination Image

A University of Szeged, Faculty of Science and Informatics, Department of Economic and Social Geography, Egyetem utca 2, 6722 Szeged, Hungary; Corresponding author: dorottya.suli@gmail.com 


\section{Introduction}

Nowadays in the choice of destinations the experience-oriented aspect of consumption comes to the fore. During the tourism decisions, there is more and more emphasis on emotions as well as others' experiences and opinions (Éber, 2008). There have been two major changes in tourism information gathering and decision making processes in recent decades. On the one hand, Internet services have been transformed, social media have evolved as new technological tools, which generate very interactive and collaborative platforms were tourists can share their travel stories, discuss, and amend user-generated content (Buhalis-Law, 2008). These contents are playing an important role in the multi-dimensional, two-way and peer-to-peer communication (Pendergast, 2010). On the other hand, there are numerous websites and platforms for informing consumers, with millions of active users.

Many industries, as well the tourism industry has greatly benefited from the new opportunities offered by the Internet technology which has disturbed the traditional information gaining process. The Internet and the new emerging social media have made a huge impact on the way people search and share experiences and even make a decision about a destination (Dudás et al., 2017). Therefore, the Internet and social media are considered as an important source of tourism information and they are constantly in the forefront of factors influencing travel decisions. Besides that, searching for information on the smartphone and mobile internet is becoming more and more important, which can be observed mainly in the $\mathrm{Y}$ and $\mathrm{Z}$ generation (born after 1980), creating new trends and opportunities for tourism (Veres et al., 2017). These young people travel a lot to diverse destinations, to different events (such as festivals) where they can enjoy community experiences. It is worth examining the behavior of these generations, as they are the travelers of the future, influencing each other's consumer habits.

Visiting the festivals provides good conditions for the creation and enjoyment of non-routine experiences, thus making festival tourism more and more popular for youngers. They mostly like music festivals, therefore we had focus on light music festivals, which are the most popular among younger generations, so we can examine the significance of new opportunities provided by technology in festival tourism. Our aim was to assess the relationship between social media usage and travel decision-making process among young festival visitors who are participating in festivals in Vojvodina and Hungary. During our research we used a quantitative and qualitative research method as well. We made an offline questionnaire survey among the $\mathrm{Y}$ and $\mathrm{Z}$ generations of two festivals in the study area (in the Youth Days of Szeged and in Green Future of Ada), and we also asked online the students from the University of Szeged, who usually visit festivals. Since social media can indirectly contribute to the awareness of festivals and settlements through the entries of the festivals, we also analyzed the posts related to festivals by a popular image sharing site (Instagram).

\section{Literature review - The role of social media in tourism}

Nowadays, when the usage of the Internet is common, the easiest and fastest way for tourists to get information about the potential travel experience is searching on the Internet. Within the Internet, the development of various interactive communication interfaces have become the decisive factor, which has been revitalized by web 2.0 technology where users together make the content and share their travel experiences (Eszes, 2007). These include various social networking sites (e.g. as Facebook, Twitter), photo and video sharing portals (e.g. Instagram, 
Snapchat), various thematic, travel-related blogs, and special tourism-related websites (e.g. TripAdvisor, Foursquare). These sites are information gathering platforms and also sharing interface for potential travelers. The techniques of gaining and sharing information have changed, making online storytelling more dominant (Glozer, 2018). Thanks to web 2.o technologies, the Internet has evolved from a 'publish-browse' platform to a 'participatory-interaction' platform (Xiang et al., 2014), that has significantly influenced and transformed the travel decision-making process (Buhalis - Law, 2008; Guerreiro et al., 2019). These communication interfaces have now evolved into dominant communication channels (Hudson et al., 2015), and Web 3.o technology can make these online experiences even more personalized, as instead of doing more searches on different website, all relevant information would be available in one place (Streit, 2014; Živković et al., 2015).

These interfaces are especially used by the $\mathrm{Y}$ and $\mathrm{Z}$ generations ${ }^{1}$, as the travel decision of the younger generation is mostly based on others' opinions and shared experiences (on recommendations). These generations have the most friends on social network sites, so the relevant information is easily and quickly accessible to them (Málovics et al., 2015). According to Streit (2014) and Málovics et al. (2015), the members of these generations are more informed, more aware, faster, more adventurous and more mobile than the previous generations in their ages. Their most important motivation in choosing a destination is to get experiences (Kovács, 2014; Iványi - Bíró-Szigeti, 2016).

Sharing experiences online, on social media sites, and keeping track of others' posts is becoming increasingly popular among $\mathrm{Y}$ and $\mathrm{Z}$ generations (Klausz, 2017). Although in user-generated content, such as websites and tourist service ratings, high personal tastes and subjectivity can be seen, nevertheless young users feel more confident and less risky making decisions based on the opinions of others (Fotis et al., 2012; Ethel, 2013). These generations trust in the opinion of the Internet community (in other consumers), rely on them, and they are very active in social media networks, where they become opinion leaders, so these networks are becoming the main and the most important and trusted source of information for them (Segarra, 2015). This is especially true for generation $\mathrm{Z}$, who are digital natives, so, they no longer need to learn how to use the Internet, since this has been the part of their daily lives since childhood (Klausz, 2017). In many cases, text messages are obsolete to them, in pictures and videos is possible to efficiently transmit information, besides that the interaction allowing channels, the creation of content and the sharing of opinions are especially important to them. That is why special attention has to be paid to young people in the marketing of different destinations, since according to WYSE Travel Confederation analysis, travel among young people has become one of the fastest growing segments of international tourism. Thus, in the coming years, it is expected that tourism will be mainly shaped by the $\mathrm{Y}$ and $\mathrm{Z}$ generations, as they enter the age to make their own tourism decisions (Mester, 2008). The decisions between destination are most often already made on the mobile Internet and on a smartphone in the pre-travel phase, and information is also searched on the Internet during their trip, so they can get quick, immediate answers and guidance (Veres et al., 2017). They completed their journey, by sharing their experiences and opinions on the web, so the internet and social media cover the entire travel process (Figure 1).

The use of different social media sites (such as photo and video sharing portals) for marketing purposes is also gaining importance, despite these sites were originally made for com-

1 In our study, according to McCridle (2012), generation Y includes those who were born between 1980-1994 and generation $\mathrm{Z}$ are those who were born between 1995-2010 


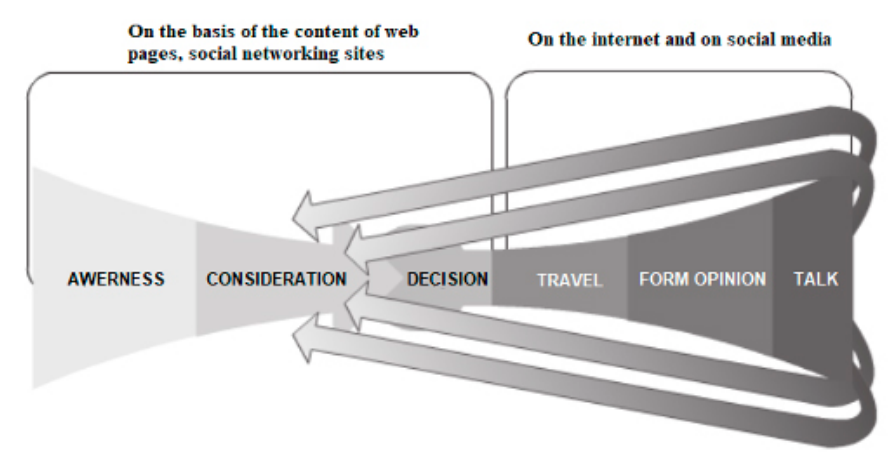

Figure 1. The role of social media in the travel related decision-making process (edited by authors, based on Ethel, 2013)

munication between individuals. Various events and destinations not only assess the needs of potential tourists by actively participating in major social networking sites, but these platforms give them access to visitors' feedback through reviews (Oklobdžija, 2015). If an event, or a branding specialist from different destinations targets these segments on these interfaces and conveys their message to them, then young people will follow and like their pages, so they will constantly receive information about it. They are loyal to beloved brands in the long run, but if the page for some reason is no longer interesting to them, it stops being liked and stops following (so they don't get any more information). Therefore, based on a well-designed brand or a well-conveyed message, the potential tourist identifies this information like quality, so it influences the content of their imagination about that brand or destination, and this can influence their travel decisions, too (Spiegler, 2010).

\section{Methods}

In the course of the research, we conducted an online questionnaire survey among the students who are participating in festivals, and we asked the participants of two music festivals on the Hungarian-Serbian border area: the Green Future (in Ada) and at the Szeged Youth Days (so-called SZIN) in Szeged. For comparability, the aim of the research was to ask the university students age group - 18 - 25 years old people -, so we could not apply probability sampling, which resulted in the overrepresentation of the examined age group. The sample was also not representative of territorial coverage, since both the online and the personal questionnaire survey were mainly answered by young people from Vojvodina (north part of Serbia close to the Hungarian border) and from South Plain (south part of Hungary close to the Serbian border). Online 84, at the Green Future 148, and at the SZIN 119 questionnaire was filled out. The survey covered several issues, in this study our aim was to assess the relationship between social media usage and travel decision-making process among young festival visitors who are participating in festivals in Vojvodina and Hungary. Since social media can indirectly contribute to the promotion of festivals and settlements through the entries of the festivals, we also analyzed the posts related to 10 examined festivals (Table 1 ) by an increasingly popular image sharing site (Instagram). 
Table 1. The examined festivals, and their organizing settlements

\begin{tabular}{|l|l|l|c|}
\hline Name of the festivals & Organizing settlement & Analyzed keywords & Number of analyzed records \\
\hline Exit & Újvidék (Serbia) & \#exitfestival2017 & 211 \\
\hline Green Future & Ada (Serbia) & \#greenfuturefestival & 182 \\
\hline Kanizsa Feszt & Magyarkanizsa (Serbia) & \#kanizsafeszt & 246 \\
\hline Malomfesztivál & Orom (Serbia) & \#malomfesztival & 6386 \\
\hline Sziget & Budapest (Hungary) & \#sziget2017 & 2828 \\
\hline VOLT & Sopron (Hungary) & \#volt2017 & 2451 \\
\hline EFOTT & Velence (Hungary) & \#efott2017 & 4412 \\
\hline Balaton Sound & Zamárdi (Hungary) & \#balatonsound2017 & 126 \\
\hline East Fest & Mezőtúr (Hungary) & \#eastfest2017 & 645 \\
\hline SZIN & Szeged (Hungary) & \#szin2017 & \\
\hline
\end{tabular}

On Instagram the searched keyword (hashtag) was simply the name of a festival (e.g. the \#greenfuturefestival, \#malomfeszt), but in the case of some major festivals we limited the search results for the year 2017 (e.g. \#exitfestival2017). As a result of the search we analyzed 19 299 public records in varying proportions from festival to festival (Table 1).

\section{The main results of the research}

It can be observed by the questionnaire survey which was filled out by festival participants in Vojvodina and Hungary, that the information gaining and the travel decision making is significantly affected by what the potential tourists saw from the social media sites. Looking at the information gaining process we can observe that interviewed festival visitors are mostly searching for information on the Internet. The online respondents used primarily Facebook community page, besides that other media contents and websites of the festivals also play an important role before the trip. It is no coincidence, because the questionnaire was shared on Facebook, but also during the personal interviews, participants identified community networks as source of information, so the internet plays a significant role in this process. Besides that, a large part of visitors still prefers to get information from their friends, but as Facebook is primarily used by acquaintances and friends, it actually enhances the traditional information gaining process with a new tool or channel. In addition, it extends the possibilities of finding recommendations by making visible posts for strangers.

During our research, we have examined whether the respondents' travel decisions are influenced by their friends' social media posts and experiences. More than half of the respondents $(62 \%)$ were interested in the published posts of others, related to travel and festival. It can be stated that not only the emerging $\mathrm{Z}$ generation, but also among the examined young adults (students) the shared posts in social media are getting more and more important. However, when we asked the participants of the research whether their decisions on visiting a place or a festival were influenced by social media posts, almost half of the respondents (44\%) said that entries had a role in decision making, in this case most of the posts influenced them positively (85\%). Even so, it is important to emphasize that social media posts can not only play a motivating role, as a negative experience can also be very decisive, which may affect the realization of travel intentions. The survey also shows that, although someone is interested in others' shared information, experiences about their travels or festivals, it doesn't necessarily have an impact 
on their decision, as $56 \%$ of the respondents did not make their travel decisions based on this. Despite the fact that less than half of the respondents were influenced by the published posts of others' in the travel decisions, but it's expected to increase, as more than half of the respondents $(66 \%)$ share their own experiences related to festivals on some social media interfaces (mostly on Facebook and Instagram). The interviewed Serbian festival visitors - who were the youngest among the respondents - use more Instagram and its hashtag function to share their experiences, which support the fact that nowadays this is the most popular image and video sharing channel for young people. Among Hungarian festival participants using Facebook for searching information or sharing experiences has been more popular than Instagram, yet. The Snapchat was mentioned in the third place by the respondents, which is becoming more and more popular in Hungary and Vojvodina, too (Figure 2).

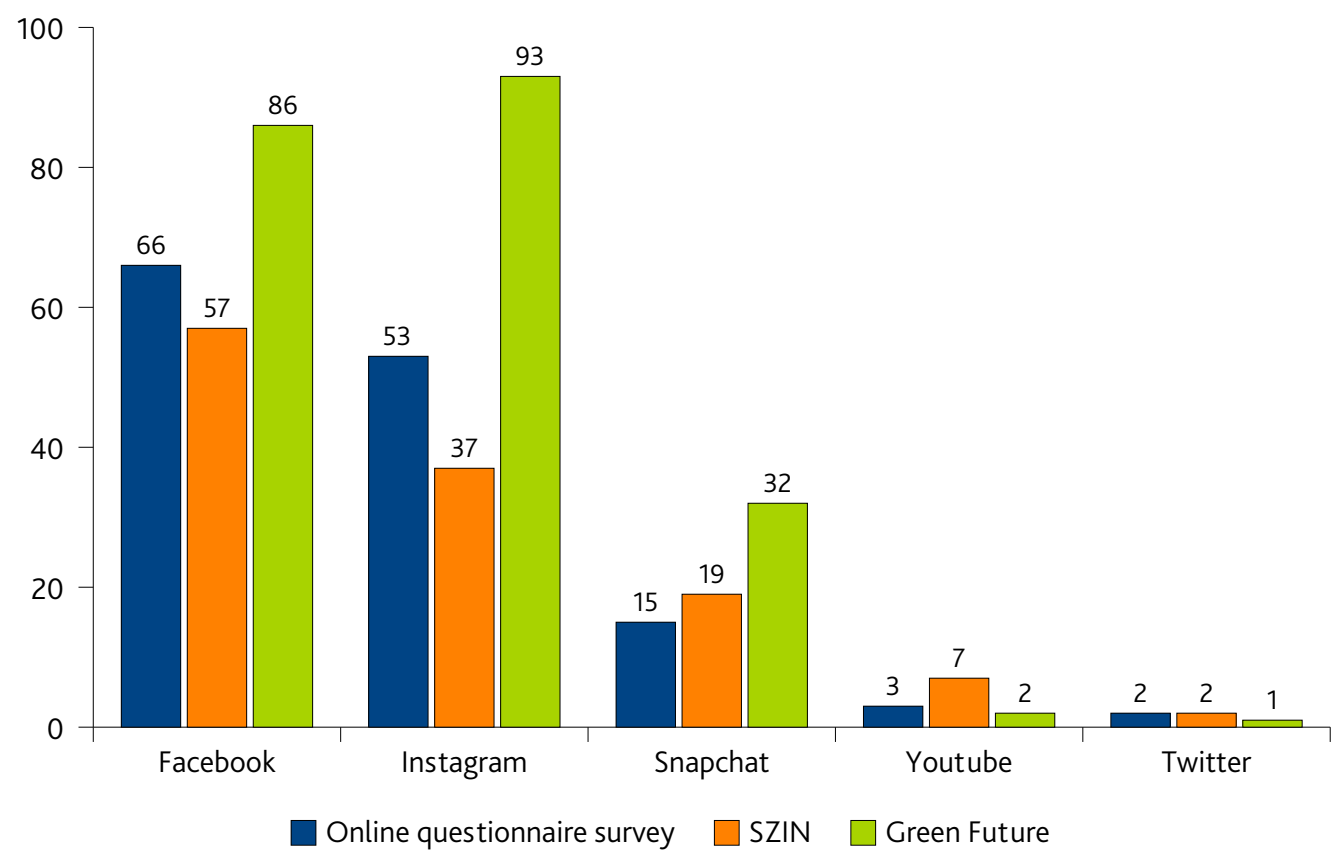

Figure 2. Distribution of experience sharing on different social media platforms (edited by authors, based on questionnaire survey 2017)

Respondents are not only sharing their experiences but they are also curious about what the others have posted. Among the respondents Facebook was also dominant in searching for shared experiences, due to that this social media site serves the best (most people-used) interface. It is true that during the sharing of experiences among the festival participants in Vojvodina - contrary to the Hungarian festival visitors -, the Instagram has been already ahead of Facebook, but if they are searching for others' posts, then the Facebook is the most important community channel for them, too. Besides Facebook, Instagram, Snapchat and YouTube community channels are also popular, but Google was also often used for searching recommendations among the respondents (Figure 3).

Examining the interest of festival participants of social media posts, it was noticeable that images, videos and after movie were mentioned most frequently at both festivals, but also live video/live login was important to them (Figure 4). Nowadays, some festivals, such as VOLT 


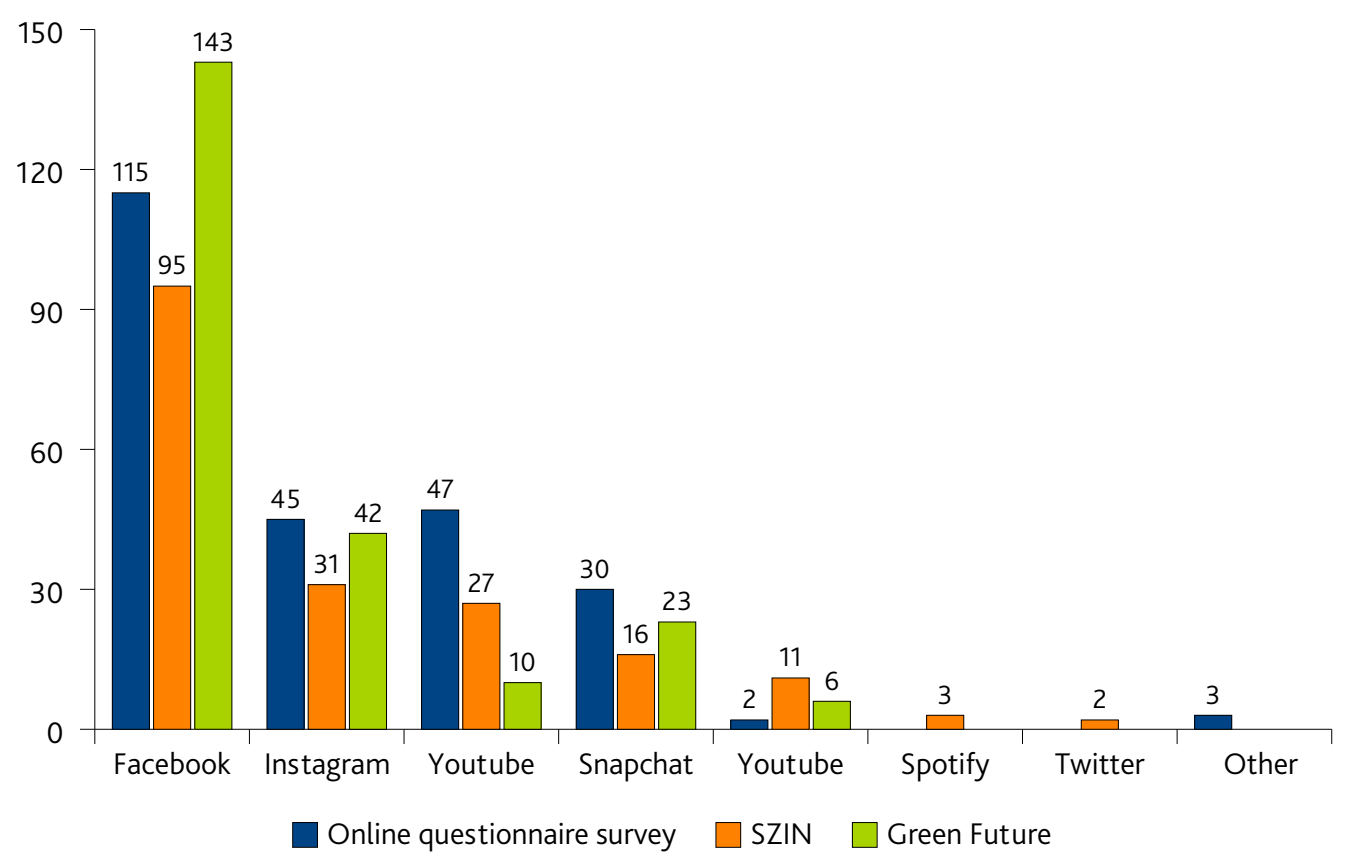

Figure 3. Distribution of searching for others' shared posts on different social media platforms (edited by authors, based on questionnaire survey 2017)

and Sziget (as well as Exit in 2020) are launching live broadcasts, so those who have been unable to get to the festival for some reason can enjoy a bit of the mood. Not only event organizers can do this, but the participants also can launch live videos on different social network sites. At the Green Future Festival, 14\% of the respondents' launch live of the festival via Facebook or Instagram, while in the case of the SZIN this proportion is $29 \%$. Of course, live videos have a negative side for tourism, as a wider audience can watch concerts and events from home comfortably and at no cost, but it can also positively influence a tourists who are looking for a real experience (Zátori, 2014) by encouraging them to make a travel decision.

In the case of Instagram, which is an increasingly popular image sharing site, these searches are done by hashtags. Users assign tags to their images, which means that these pictures or videos are tagged with keywords, making it easier to search for entries. Instagram is primar-

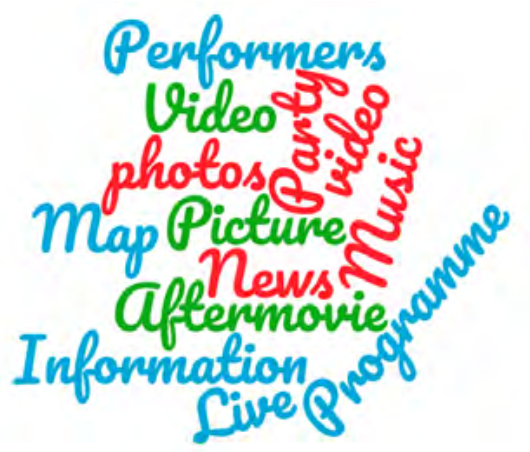

Figure 4. Most searched online posts among festival participants (edited by authors, based on questionnaire survey 2017) 
ily a place for brand building, where the brand can be enhanced with life-like images, videos (Lévai, 2016), so the users' hashtags can contribute to increasing the popularity of some settlements or festivals. Searching for a particular hashtag, all posts with those labels will appear, and the experiences can be viewed. For example, if potential tourists are browsing for a festival, the settlement that organizes it may also appear between the labels and vice versa. They can see any public shared experiences that also influence their travel related decisions. In addition, the festival and the settlement can strengthen each other's image and raise awareness/popularity. Thus, in the case of Instagram posts, we analyzed how close is this relationship between the festivals and the host-settlements, and how much can the festival contribute to the promotion of the settlement (Figure5).

Among the analyzed hashtags, in the case of Green Future, we found from 211 posts only 29 references to Ada (13.7\%), while related to SZIN festival, Szeged (the host-settlement) was mentioned in some form 252 times out of 645 posts (39\%) (Figure 5). In the case of Green Future, the most common hashtag was also simply the name of the settlement: \#ada (20), besides, there was also \#adica (the place of the festival) and \#adatour (a created name from the city and tourism). In the case of SZIN, most of the posts were only tag \#szeged (197), but the \#szeged \#iloveszeged (14) and the \#szeged \#suncity (10) keywords have occurred together. We found references also for other parts of Szeged (e.g. Votive Church, bank of Tisza river). For \#sziget2017, we found 2579 references to the settlement out of analyzed 6386 posts, which is the highest mentioning rate $(40,4 \%)$, so there is a strong connection between the Sziget Festival and Budapest (the host-city). The most common hashtag of the analyzed keywords was the name of the city (2 492), but \#obuda (15) and the \#budapestgram (14) occurred several times. In the case of the VOLT festival, we found 900 references out of 2828 public entries, which is

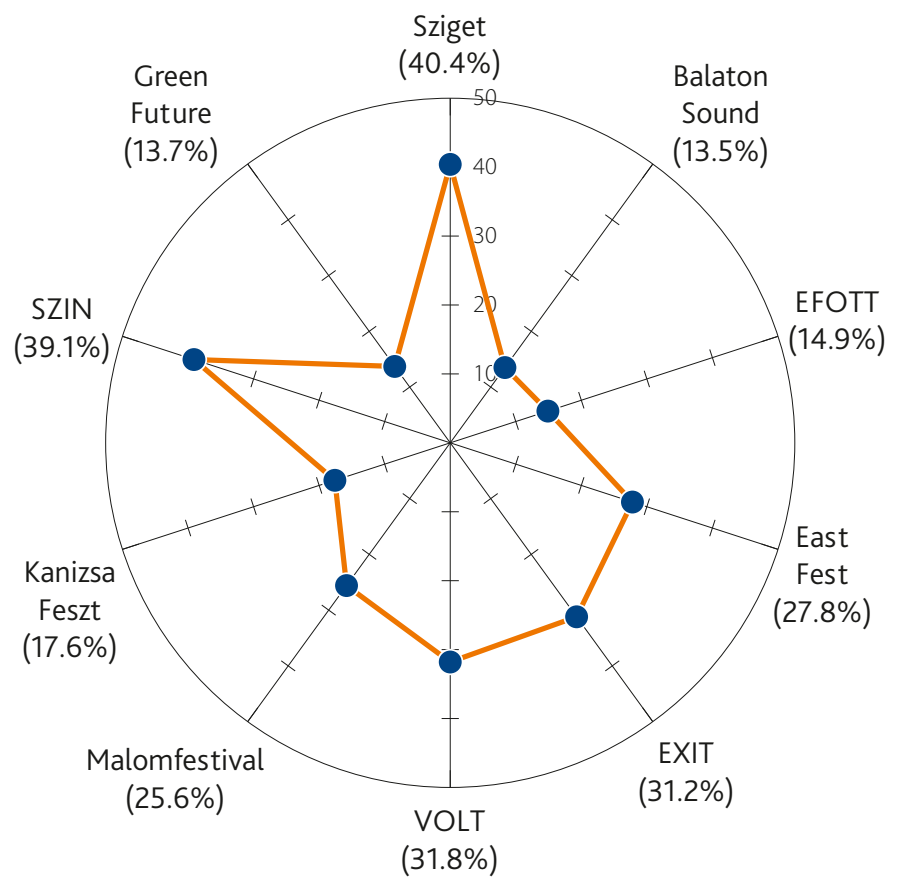

Figure 5. The proportion of the mention of the analyzed festival's host towns in all the posts relating to the festival

(edited by authors, based on the research on Instagram 2017) 
the second-best mentioning rate of the analyzed Hungarian festivals. Most of the respondents came from Vojvodina, from South Plain and from Central-Hungary, so VOLT was well known even though most of the respondents did not come from the region of the festival (west part of Hungary) (Figure 5). The VOLT festival has also produced a good result from previous research too, so there is a really close relationship between the town and the festival, therefore they can mutually contribute to strengthening each other's image and attracting more visitors.

In the analysis of the 126 public posts of the \#eastfest2017, we found references for the settlement in 35 entries, which is the third best rate of the analyzed Hungarian festivals (Figure 5). This result was also shown in the questionnaire survey, where nearly all respondents were able to link the festival to Mezötúr. In the case of Exit, in the 1812 public posts, we found a connection to the host settlement 566 times, in which the most commonly used keywords were \#novisad (the town) and \#petrovaradin (the name of the place). This mentioning rate $(31,2 \%)$ is the best of the analyzed festivals in Vojvodina. During the analysis of the Balaton Sound Festival (\#balatonsound2017), between 4.412 posts we found only 595 links to Zamárdi (the host-settlement) in some form (13,5\%), which is the worst mentioning rate among all the festivals involved in the survey (Figure 5). This weak link was also observed during the questionnaire survey, although it is a significant and long-standing festival. In the case of the EFOTT festival, we have found 2451 posts, where Velence (the host-settlement) was only 366 times mention among the hashtags (14.9\% mentioning rate). During the analysis of the Malomfeszt, in Orom, due to the low number of posts we have also reviewed the \#malomfesztival and the \#malomfesztivál keywords. We found 246 posts, where the settlement was mentioned 63 times, so it is still quite a weak reference to the settlement, but compare to the fact that this is a new festival, we can observe the second best mentioning rate $(25,6 \%)$ among the analyzed events in Vojvodina (Figure 5). Finally, in the case of the Kanizsafeszt, from 182 posts we found only 32 references to Kanizsa, which seems very few taken in consideration that the name of the settlement appears in the name of the festival.

\section{Conclusion}

This paper contributes to the literature on the use and impact of social media in the travel planning process among $\mathrm{Y}$ and $\mathrm{Z}$ generations. In tourism, potential tourists' behavior has always been influenced by developments in Information Communication Technologies, but especially Web 2.o has fundamentally changed the way how (young) tourists search, find and share experiences about tourism suppliers and destinations. Social media is more effective in giving potential tourists information on a destination than alternative sources. Users trust the community's opinion and they feel that they can make more informed travel decisions because of others' opinions, and social media contents often act as a motivational factor to visit a destination (Xiang - Gretzel, 2010). Different social sites are becoming more and more popular among young people in Vojvodina and Hungary, which will cause a major change not only in the pre-travel phase, but also during and after their trips.

In our research, a significant proportion of the young participants of festivals use the internet for browsing. For searching information and sharing experiences they especially use some different social networking sites (about 55\% of them use Facebook). The taken photo, video, or live sign-up is instantly uploaded to a social media site (such as Facebook) or to an image- or video-sharing portal (such as Instagram), so the experience is not only enjoyed by the person who was living it, but acquaintances and even completely unknown people may 
also be involved. More than half of the respondents (66\%) share their experiences on some social media sites (mostly on Facebook and on Instagram). Searching for others' experiences is also popular among young people, $62 \%$ of them is interested in others' posts related to travel and festival. Among the respondents, Facebook is the most used interface for searching travel related posts, but also Instagram, Snapchat, YouTube and Google are popular. These entries may influence the others travel decisions, because almost half of the respondents (44\%) were influenced by other's experiences and mostly in a positive way (85\%). If the shared experience is positive, it can motivate others to travel, but some bad experiences, negative shared content can eliminate travel motivation. In our research, some people' (15\% of the respondents) decision was negatively affected by the posts that they have seen before, so it can be concluded that shared experiences also can have a bad effect on tourism. In contrast to Facebook, which is the most commonly used social interface, where shared posts can affect travel intentions mainly among friends and acquaintances, Instagram gives the opportunity to everyone to search for places and events by using headlines. This way, we can track the images and videos of different people without even knowing them, which may influence travel decisions even more widely.

The results of the research on Instagram confirm that festivals can play a major role in knowing a region or a destination, shaping the image of the settlement, and spreading it to a wider audience. The analyzed Instagram posts suggests that the closest connection between the festival and the settlement is likely to be in the case of the Sziget and the VOLT Festival. So, they can contribute to increasing each other's awareness and strengthening a positive image. However, the size and reputation of a festival do not necessarily coincide with the fact that the respondents also know the settlement that is organizing the event, which can be seen in the case of Balaton Sound, where the organizing settlement is unknown to many people. It can be observed in the analysis of hashtags, that in the case of the Exit and the Malomfesztivál, the mentioned rate of the organizing settlement or the festival location is high, so it can be stated that, despite the novelty of a festival and the small number of posts on the Instagram, the reference to the settlement can be high (e.g. Orom - Malomfesztivál). Examining the festivals and image enhancing effects, it can be stated that in the posts related to the festivals on Instagram references to the host settlements appeared, which suggests that some festivals can really contribute to shaping the image of the organizing town and increasing its awareness.

\section{References}

Buhalis, D., Law, R. 2008. Progress in information technology and tourism management: 20 years on and 10 years after the Internet - The state of eTourism research. Tourism Management 29(4), 609-623.

Dudás, G, Boros, L., Vida, Gy. 2017. Comparing the temporal changes of airfares on online travel agency websites and metasearch engines. Tourism 65(2), 187-203.

Ethel, L. 2013. Impacts of social media on consumer behavior - Decision Making Process, International Business. http://www.theseus.fi/bitstream/handle/10024/62367/Lee Ethel. pdf?sequence $=1$ \&isAllowed $=y$ (downloaded: 2019.11.19.)

Eszes, I. 2007. Web 2.0. ESZES könyvtár. http://www.eszes.net/eTanulmanyok/web2.pdf (downloaded: 2019.11.19) (In Hungarian)

Éber, M. Á. 2008. Túl az élménytársadalmon? - avagy az élménytársadalom másfél évtizede. Szociológiai Szemle 18(1), 78-105. (In Hungarian) 
Fotis, J., Buhalis, D., Rossides, N. 2012. Social media use and impact during the holiday travel planning process. In: Fuchs, M., Ricci, F., Cantoni, L. (Ed.) Information and Communication Technologies in Tourism, 13-24.

Glozer, R. 2018. Jönnek az „Instagram-inasok”? - az Instagram szerepe és lehetőségei a turizmusmarketingben. In.: Generációk a turizmusban. I. Nemzetközi Turizmusmarketing Konferencia tanulmánykötet, Pécs, 223-237. (In Hungarian)

Guerreiro, C., Viegas, M., Guerreiro, M. 2019. Social networks and Digital influencers: their

role iN customer decision journey in tourism. Journal of Spatial and Organizational Dynamics $7(3), 240-260$.

Hudson, S., Roth, M., Madden, T., Hudson, R. 2015. The effects of social media on emotions, brand relationship quality, and word of mouth: An empirical study of music festival attendees. Tourism Management 47, 68-76.

Iványi, T., Bíró-Szigeti, Sz. 2016. Oszd meg és hashtagelj! - Közönségrészvétel és élménymegosztás a turizmusban. In: Fehér A., Kiss V. Á., Soós M., Szakály Z. (Ed.) Hitelesség és értékorientáció a marketingben. Debreceni Egyetem Gazdaságtudományi Kar, Debrecen, 706715. (In Hungarian)

Klausz, M. (Ed.) 2017. Megosztok, tehát vagyok: Szakértői kérdések és válaszok a közösségi médiáról. Athenaeum Kiadó, Budapest (In Hungarian)

Kovács, D. 2014. Élmény, élménygazdaság, élménytársadalom és turizmus. Turizmus Bulletin 16(3-4), 40-48. (In Hungarian)

Lévai, R. (Ed.) 2016. Hogyan készits eredményes Facebook hirdetéseket? RG Stúdió, Pécs (In Hungarian)

Málovics, É., Prónay, Sz., Kincsesné, Vajda B. 2015. Az „Erasmus-nemzedék” útra kel - Y generációs egyetemisták külföldi utazási motivációinak és szokásainak feltárása. In.: Marketing E Menedzsment 2015(1), 43-57. (In Hungarian)

McCrindle-Research 2012. Generations Defined. http://mccrindle.com.au/resources/Generations-Defined-Sociologically.pdf (downloaded: 2019.07.05.)

Mester T. 2008. Ifjúsági turizmus Magyarországon - I. rész. Turizmus Bulletin 12(2), 2-13. (In Hungarian)

Michalkó, G. 2014. Városimázs és versenyképesség: a turizmusorientált településmarketing néhány aspektusa. In: Tózsa I. (Ed.): Turizmus és településmarketing. Budapesti Corvinus Egyetem Gazdaságföldrajz és Jövőkutatás Tanszék, Budapest, 37-47. (In Hungarian)

Oklobdžija, S. 2015. The role and importance of social media in promoting music festivals. Synthesis: Marketing and Trade, 583-587.

Pendergast, D. 2010. Getting to Know the Y Generation. In: Benckendorff, P. - Moscardo, G., Pendergast, D. (Ed.): Tourism and Generation Y. Boston: CAB International.

Segarra, J. P. 2015. The vision of Tourism 3.o. https://app.box.com/s/uci8ireztqflcxrps3lvcu763bmptoqz (downloaded: 2019.11.05.)

Spiegler, P. 2010. Turisztikai tér-képek a Dél-Dunántúlról. In: Görcs N. L., Pirisi, G. (Ed.): Tér Tálentum - Tanitványok II., Pécs, 125-136. (In Hungarian)

Streit, E. 2014. A fiatal generáció utazási döntéseinek marketingszempontú elemzése. In.: E-CONOM. Online tudományos folyóirat, 66-79. (In Hungarian)

Veres, I., Danó, Gy., Iványi, T. 2017. Osszunk vagy ne osszunk? Fiatalok utazási szokásai és élménymegosztás. In: Bányai, E., Lányi, B., Törőcsik, M. (Ed.): Tükröződés, társtudományok, trendek, fogyasztás. Pécsi Tudományegyetem, Közgazdaságtudományi Kar, Pécs. 75-84. (In Hungarian) 
Xiang, Z., Gretzel, U. 2010. Role of social media in online travel information search. Tourism Management 31(2), 179-188.

Xiang, Z., Wang, D., O'leary, J. T., Fesenmaier, D. R. 2014. Adapting to the Internet: Trends in Travelers' Use of the Web for Trip Planning. Journal of Travel Research 54, 511- 527.

Zátori, A. 2014. Élményszemlélet a turizmusban. A turisztikai élményteremtés koncepciói. Turizmus Bulletin 16(2), 51-60. (In Hungarian)

Živković, R., Gajić, J., Brdar, I. 2014. The impact of social media on tourism. SINTEZA: E-Business in tourism and hospitality industry, 758-761. 